doi: 10.14267/cojourn.2019v4n2a1

\title{
Reassembling a World Order: Toward a New Historiography of the Paris Peace Conference
}

\author{
Tamás Péter Baranyi ${ }^{1}$
}

\begin{abstract}
The evaluation of the Paris Peace Conference or the "Versailles-Washington world order" is one of the most widely discussed subjects in the study of history and international relations. The abundance of research and assessment is partly down to the formative character of the post-WWI peace on the national consciousness of many states and to the term 'Versailles' which has become an oft-recurring keyword in the analysis of international relations. Due to the sheer volume of accounts, a historiography of the Paris Peace Conference is inevitably a collection of the author's own discretion. This paper focuses on the international historiography of the Paris Peace Conference and its consequences, and argues that after the consolidation of orthodoxies following 1919, and the triumph of revisionist history in the late-1980s, the scholarly community is now experiencing another reappraisal - beginning from the $2010 \mathrm{~s}$.
\end{abstract}

Keywords: Versailles, historiography, international order, Americanization, postcolonial criticism, war guilt, empire, nation-state, nationalism, identity

\section{A 'Seminal Catastrophe'}

A number of attendants at the Peace Conference were themselves historians, and all sorts of academics were present to provide scientifically grounded advice for the conference: Harold Tamperley, R. W. Seton-Watson, Charles Seignobos, Émile Boutroux and Harold Nicolson, to name but a few (Irish, 2016; Nielson, 1992). Such first-hand experience contributed to a surge in historical studies later on.

\footnotetext{
${ }^{1}$ Tamás Péter Baranyi is Head of Research at Antall József Knowledge Centre and Adjunct Professor at Pázmány Péter Catholic University. The focus of his research is modern and contemporary diplomatic history, international relations, and security.
} 
doi: 10.14267/cojourn.2019v4n2a1

Not long after the conference, both sides assembled relevant documents about what led to the Great War. Harold Temperley and G. P. Gooch started to work on a documentary series already in 1926: the British Documents on the Origins of War (Gooch-Temperley, 1926). Harold Nicolson, already aware of the historical significance of peacemaking in 1919, and studying the Vienna Congress of 1815 during those days, made two important contributions: the publication of his Peacemaking 1919 (1933) about Paris, and his A Study in Allied Unity (1946) about the Vienna Congress (Nicolson, 1933, 1946). R. W. Seton-Watson, an ardent activist and supporter of 'autonomies' in Eastern Europe, also published his The Origins of War in 1926. Most of the early works tried to prove Germany's extranormal behavior that had led to war in 1914. The British collection of documents edited by Temperley and Gooch was more balanced due to the involvement of Gooch, whose professional interest was German history. He was specifically asked to take part for this reason, to make the opus less biased.

Academics sought answer to the question whether the settlement was just and effective. The most debated point to emerge was the 'origins of World War I,' i.e. who bore responsibility for the outbreak of the war. This held major implications: if Germany could be proved to have been the ultimate aggressor then even a 'Carthaginian peace' could be justified - while if the Entente powers were those who bullied Germany into war then harsh peace terms may qualify as outright predatory. To determine this issue was the purpose of the documentary collection of Temperley and Gooch-but it also had a German counterpart, the 40-volume Die Grosse Politik der europäischen Kabinette. The German Foreign Office employed a complete section for investigating 'war guilt' and supplying material to attack its basis in international politics. Later on, French and Russian collections were also assembled. Gyula Andrássy Jr., the last foreign minister of Austria-Hungary, published his Diplomacy and World War in the mid-1920s. With those collections a major problem was their presupposition that the most important decisions were made in cabinet offices and ministries. They thus downplayed social developments and the role of the militaries (Mulligan, 2016).

The second issue of debate was whether the losses of the defeated countries were acceptable or not in a civilized framework. The idea that the Versailles settlement was a 'Carthaginian peace' sharply divided international public opinion.

A third issue was national self-determination - a legal notion that became the cornerstone of the post-war settlement in spite of its essentially contested nature. How could one claim self-determination for oppressed nations on the one hand, and disregard 
doi: 10.14267/cojourn.2019v4n2a1

the same demand from others? The idea of Wilsonism and liberal internationalism was clearly in contradiction with the outcomes in many cases. Yet, as the logic of much early scholarship implied, if the settlement was practical and beneficial, then it must have been the result of the infusion of Wilsonism into European politics. If it was not, however, than the question becomes whether it was predatory and ignorant because of or in spite of Wilsonian ideas (cf. Anievas, 2014: 619-620). If Wilson's intentions were the best and the results of the treaty were devastating, how did the process of implementing Wilson's programme end up derailed? A fourth major question was the economy: did the settlement create the framework for a European reconstruction with which the war could be ended not only between the armies but between the treasuries as well? Or was it non-viable from the beginning, only to lead to further deteriorating conditions? This last question was probably the first to be studied seriously in the early stages.

The most influential historiographical piece did not come from historians - rather from a delegate of the British Treasury, John Maynard Keynes. He was urged to make an account by the South African statesman Jan Smuts (Bottom, 2004: 8). Keynes wrote his seminal work on the Peace Conference in a very short period of time: The Economic Consequences of Peace came out in 1919. Keynes' work cemented his role as the leading economist of his age, provided munition for those already disenchanted by the Paris Peace Conference, and set up a line of thought that many would follow in the mid-20th century. On the other hand, Keynes' book was sketchy, mostly concentrated on the economy, and did not take the political context much into account. He characterized the Treaty of Versailles as a 'Carthaginian peace', i.e. as one that was insensitive to the vanquished and economically short-sighted. Later historiography and assessment basically did away with this notion - albeit only at the beginning of the 21 st century. Keynes' theses were often cited as prophetic: he maintained that the economic devastation of Europe, one-sided entente policies, and Germany's rightful sense of humiliation would inevitably lead to another arms race and war.

Another interpretation which took shape in the earliest days was the MarxistLeninist interpretation, formulated by Lenin himself. At the Third International, he said, "Versailles has proved even to the stupid and blind [...] that the Entente was and is as bloody and filthy an imperialist predator as Germany" (Lenin, 1919). As the hopes for a wildfire-like world revolution faded away, Lenin and the Bolsheviks hammered out a different interpretation which amusingly combined teleological internationalism with Russian realism. In essence, Lenin argued that the nations punished with the peace treaties 
doi: 10.14267/cojourn.2019v4n2a1

were by then colonies in all but name, and their sufferings and humiliation would eventually lead to further crises of capitalism. The idea that war emanated from intracapitalist crises, and peace only further sharpened them, became the blueprint of Soviet strategic thinking. It was not only an analysis but a plan for action. The humiliated masses would search for a leader and now Germany — dispossessed by the capitalist world order-would take this position (Harding, 2009: 244-249). A continuation of this line of thought could be that the advanced capitalist powers managed to subjugate Eastern European nations into a quasi-colonial status. From a Bolshevik perspective it may be lamentable - but more importantly, it provided an opportunity to react to 'predatory' capitalism. Marxist interpretations proved surprisingly resistant to change through time and were canonized as the only acceptable outlook in Soviet Russia, and among most Communists and radical Socialists. It did not, however, penetrate into non-extreme Leftist thinking at the time: the local Left typically framed the treaty in local terms, e.g. the Hungarian socialists blamed the pre-war Hungarian élite (cf. Romsics, 2014: 668-672).

Aside from official policy, American interpretations among the more liberal sections of society began to emerge right after the war. Apart from a critical realist tradition, official sentiments in the U.S. were often characterized by the work of Ray Stannard Baker. He was press secretary to President Woodrow Wilson during the conference and caretaker of the president's papers. Baker published The Public Papers of Woodrow Wilson in six volumes (1925-1927) and Woodrow Wilson: Life and Letters in eight volumes (1927-1939). In this standard American view, President Woodrow Wilson was a heroic leader whose mission was thwarted by cynical European leaders. In fact, the growth of anti-European sentiment was apparent in interwar American historiography (Widenor, 1998: 548-553).

This American development was in serious contrast to the British public opinion. For the latter, revisionism came so early and became so pervasive that it became "more dominant than the interpretation that was intended to be the orthodoxy" (Fry, 1998).

Similar bifurcation can be observed in most national historiographies: defeated powers - or who perceived themselves as such — adopted arguments and approaches from revisionist, Keynesian, or Leninist interpretations, while those conceived as 'winners' and the East European 'successor states' tended to build on 'internationalist' narrativeswhile engaging in nationalist nation-building at home (Zimmer, 2013: 2-7).

The coming World War II meant that the terrible consequences the peace was foretold to create in some of the abovementioned narratives would ultimately prove real. 
doi: 10.14267/cojourn.2019v4n2a1

The British public started to see Germany as a 'valiant foe' disproportionately and dishonestly punished by a haughty ally. The official French ideology, and her East European allies, espoused a strong sense of achievement related to the Great War and the enormous work the Peace Conference (Orzoff, 2009). Keynes himself was even declared persona non grata in France (Sampaio, 2016). The same can be said of the reputation of Keynes' work by then: while it has been translated to both German and Hungarian already in 1920, a Romanian translation was not produced during the interwar years. With the 'Versailles order' crumbling, the prestige of the late President Wilson-and that of liberal internationalism as such-was also on the ebb.

Criticism even reached the personal traits of President Wilson: William C. Bullitt - a young diplomat present at the peace conference and later the U.S. ambassador to Moscow-co-authored a book on the president's mental character with Sigmund Freud. Bullitt, influenced by his experience of being sidelined at the Paris negotiations, disparaged President Wilson so much so that the book could not come out for decades (Kennan, 1962). The final years before WWII somewhat changed this anti-Versailles mood: Ray Baker was awarded Pulitzer Prizes for his books on Wilson, and a positive assessment - albeit modified — was cautiously put forward. According to this new interpretation, Wilson remained courageous and good-willing throughout the peace conference but his untainted American ideas were compromised by shrewd European leaders and his own chief advisor Colonel House. Foremost among those proposing this view was Paul Birdsall in his 1941 Versailles Twenty Years After (Tanner, 2004: 49-52). This dichotomy of American naivety and cosmopolitan European shrewdness was a major leitmotif of interwar American literature and it may have been reverberated by such an appraisal of the activities of President Wilson.

The coming of the Second World War on the one hand provided a canvas against which the story of the Versailles peace could be interpreted while the war itself eclipsed its importance. The rise and fall of Nazi Germany had a twofold effect: it diminished sympathy for Germany even as it added to the blaming the Versailles diktat for the gradual undoing of Europe in the interwar years. The British historian A. J. P. Taylor's The Course of German History, completed in 1944, aimed at informing the conquerors what kind of country they set out to govern. Taylor's strict verdict and pessimistic outlook was later refined but one postwar tradition highlighted by his work was an assumed 'direct link' between 'Prussian militarism' and Nazism. On the other hand, German historians, among them Gerhard Ritter in the first place, emphasized the aberration that Nazism 
doi: 10.14267/cojourn.2019v4n2a1

constituted in German history and pointed to the flawed but still civilized or 'normal' nature of the Wilhelmine Reich. In the 1960s, the so-called Fischer Controversy was a major development in the Federal Republic: the historian Fritz Fischer argued that it was indeed German obsession with war that resulted in the outbreak of the war-and thus the war guilt claim was at least partly justified, he concluded. Fischer's views gradually gained appreciation and by the late-1960s represented a new orthodoxy in German historiography (Mulligan, 2016).

Eventually an anti-treaty school of American public thinkers emerged-building on the traditions of Theodore Roosevelt, Henry Cabot Lodge, etc.- - a realist critique of the Versailles settlement as well as American Cold War policy thereby also arose: in the works of Hans Morgenthau, George F. Kennan, or Norman A. Graebner. On the other hand, those who were forming a public discourse on the U.S. role in the world emphasised the idea of 'a second chance' to set the course of American foreign policy right. The Wilsonian approach was regarded as providing the moral underpinnings for a Cold War consensus on an active U.S. foreign policy (Ambrosius, 1977: 199, 213). Wilsonism, from this time on, became intellectual shorthand for the emerging 'interventionist' consensus in Washington.

What was possibly one of the major sources of reassessment went perfectly unnoticed at the time. Henry Kissinger's 1954 thesis at Harvard examined the 1815 Congress of Vienna and praised its commitment to restraint and the balance-of-power principle. A relative unknown at the time of writing his thesis, Kissinger was destined to become one of the major influences in the historiography of Versailles, even as, in the late-1960s, New Left history emerged in the U.S., with direct links to political opposition movements in the U.S. As Ambrosius points out, the heated criticism of the Vietnam war, a key point in New Left discourse, itself was an offshoot of Wilsonian thinking. The New Left targeted the realist concepts of foreign policy and mostly viewed Wilson's effort to make peace at the end of WWI as genuine and just, only to be corrupted either by American domestic policies, by the personal deficiencies of key leaders, or by European partners as such (Ambrosius, 1977: 202-206).

Perhaps one of the most important works written under the influence of this type of thinking is Politics and Diplomacy of Peacemaking by Arno J. Mayer for whom the idealist, internationalist impulses of Wilson were derailed by what he perceived as the counterrevolutionary structural forces. He considered the events of the Russian Revolution paramount to the understanding of the Paris Peace Conference and thought 
doi: 10.14267/cojourn.2019v4n2a1

that the Versailles settlement was a pre-emptive counterrevolutionary strike. Before his work, the immense impact of Bolshevism on Wilsonianism was underplayed. He is also credited with the introduction of the simple but powerful dichotomy of "Lenin vs. Wilson" (Mayer, 1967; Trachtenberg, 2000; Manela, 2007).

By the 1960s, 'trenches' in historiography were quite clear: socialist historiography in Eastern Europe championed different variants of the Leninists tradition, condemning Versailles as a 'carnival' of imperialist predators; while most American and British historians thought that the intentions were good but the result was disastrous. They thus tried to figure out what went wrong; in the meantime, continental Europeans emphasised Germany's paramount responsibility even as they discarded the peacemakers as short-sighted and incompetent at best (Kissinger, 1994). On the other side of the Atlantic, the most influential piece that exemplified the "postwar consensus" was A. J. P. Taylor's The Origins of the Second World War in which he argued that the failures of the Versailles treaty system, its illegitimacy, immorality, and strategic lopsidedness sowed the seeds of destruction of WWII (Taylor, 1961). The paramount American strategic thinker George F. Kennan succinctly summarized this outlook calling the First World War 'the seminal catastrophe' of the 20th century.

\section{A new scholarly consensus}

From the late-1960s on, the study of the Versailles settlement was infused with new inputs in a remarkably dual way. First, the archives were finally opening their doors, allowing researchers to broaden their base of primary sources, while historians were increasingly preoccupied with social developments as opposed to pure diplomatic history. All of this resulted in a number of new findings and approaches: a more precise reconstruction of diplomatic transactions, and an attempt to thoroughly understand social backgrounds. This is a time when Alltagsgeschichte, or the history of war and peace seen from below, came to fashion in Germany and also in broader international historiography (Horne, 2014: 623).

As the archives were opening after the expiry of the regular fifty-year rule, a renewed interest in the war came to fruition. The most important were the British archives due to the more committed recording traditions of the British cabinet (BoemekeFeldman-Glaser, 1998: 4-10). Organizational and bureaucratic matters of the conference were also coming to the forefront. A one-time British representative of the conference, Sir Harold Nicolson, published his own research-based memoirs in 1967, 
doi: 10.14267/cojourn.2019v4n2a1

which paved the way for this approach. According to Nicolson's argument, a huge bureaucracy met contradictory issues and wait-and-see politicians, and this resulted in a crisis of priorities and attention (Nicolson, 1933; Tanner, 2004; Lukacs, 2013; Marks, 2013). Michael Dockrill and Zara Steiner were following this line of research when they reconstructed how the administration of foreign policy was challenged by politics and international realities during the conference (Dockrill-Steiner, 1980).

The French, hitherto the staunchest defenders of the Versailles settlement, started to revise their outlook in the late 1970s, while, a few years later, there emerged a fresh interest in small states' approaches and economic history (Boemeke-Feldman-Glaser 1998: 4-10). Pierre Renouvin's focus on the November 11 armistice was a groundbreaking work in 1969, just like Pierre Miquel's attempt to focus on French public opinion. David Stevenson concentrated on Franco-American relations. Marc Trachtenberg in turn dealt with reparations, their supposed function, and their impact on the interwar years (Renouvin, 1969; Miquel, 1972; Stevenson, 1979; Trachtenberg, 1980). The late 1980 s then saw the first attempts at synthetizing the new approach. Henri Soutou's L'Or et Sang (1989), Alan Sharp's The Versailles Settlement (1991), and the essay collection Versailles Revisited (1998) deserve distinguished attention.

Georges-Henri Soutou's L'or et sang used an abundance of new sources aiming at a redefinition of the war aims of the warring parties. Contrary to earlier notions taken at face-value, L'Or et sang made it clear that the Entente and the Central Powers had specific and reasonable war aims. This entailed neither a defense of 'moral values', nor a quest for world domination. Both France and Germany longed for broadening the territories under their economic sway so as to gain the upper-hand in postwar Europe. France's proposal to include Belgium, Luxembourg, and possibly the Rhineland in a French-dominated customs union, coupled with the re-annexation of Alsace-Lorraine showed a striking similarity in nature and even some overlap in territory with the German Mitteleuropa concept, which would include Belgium, Germany, Austria-Hungary and future Poland. With the clarification of opposing war aims, the diplomatic maneuvers of the last months of the war as well as the proceedings of the Paris Peace Conference became less of an ideological and more of an economic matter (Soutou, 1989).

Alan Sharp's 1991 The Versailles Settlement set the tone for a new judgment of WWI's ending. Sharp did not hide the deficiencies of the peacemakers, although hebased on Lloyd George's own assessment—claimed the problems the peace conference was facing were even more momentous than the Congress of Vienna did once, as they 
doi: 10.14267/cojourn.2019v4n2a1

did involve more than one continent. It is not surprising that the task proved to be insurmountable, especially given the fact that there were no enforcement mechanisms put in place after the conference. Neither the British, nor the Americans were willing to maintain 'the Versailles order' while the French were running out of means. Circumstances indeed led to another war in 1939, but it was not a determined course from the conclusion of the peace (Sharp, 1991).

Perhaps the most influential piece of scholarship that mirrored this newer approach was the volume published by the German Historical Institute in 1998, edited by Manfred F. Boemeke, Gerald D. Feldman and Elisabeth Glaser. The most relevant piece for the purpose of this study was written by William R. Keylor. His "Versailles and International Diplomacy" became the highest quality manifestation of the question of how to evaluate the Paris Peace Conference in the light of recent findings. In his superb account, he deconstructs three major topoi of the settlement. First, the notion of open diplomacy that actually resulted in the most secretive type of proceedings at the conference (Keylor, 1998: 481-485). Second, the reparations question and the 'war guilt clause:' he convincingly argues that the latter was indeed a legal trick included in the treaty as a guarantee against which payment conditions of Germany could be eased (Keylor, 1998 487-501). On the other hand, Trachtenberg points out the 'punitive measures' present in Wilson's thinking and his determination to teach 'a historic lesson' to the transgressor Germany. Even if the 'war guilt clause' was not to stigmatize Germany, the whole discourse of postwar internationalism was in fact humiliating and short-sighted (Trachtenberg, 2000: 199-200).

Third, Keylor elaborated on the issue of self-determination and its relationship to Wilsonism. According to his assessment, self-determination was adopted late in the process and its ultimate fate to become a blank check for nation-states was a Europeanization of the principle. On the other hand, it was never applied to either West European nations or to those under colonial rule (Keylor, 1998: 476, 495). Fourth, Keylor sheds fresh light on the real meaning of the long-term effects of the territorial reconfiguration of Europe. As he points out, the weakest link of the 'Germanic alliance,' i.e. Austria-Hungary, was partitioned, while a little modified German unity was actually consecrated at Versailles. Furthermore, as the war was raging on the territory of the actual victors and resulted in the destruction of most of their industrial capacities, while the defeated power was never occupied, the 'new Germany' was not only almost whole but also economically intact (Keylor, 1998: 495-498). On the whole, allied statesmen 
doi: 10.14267/cojourn.2019v4n2a1

expressed "a remarkable degree of flexibility, pragmatism and moderation" (Keylor, 1998: 471) and it was far from being a "Carthaginian peace," and did not in fact cause the horrors of the interwar years and World War Two (Keylor, 1998: 490-491).

The role of the leading peacemakers was also reassessed, with Clemanceau absolved of most of the claims of vindictiveness (Soutou, 1998), while Lloyd George's assessment turned somewhat more negative due to his insistence on the inclusion of military pensions in the German reparation issue (Lentin, 1998). Marc Trachtenberg did not agree with the more positive assessment expounded by Keylor: "With a little more honesty $[\ldots]$ and above all a little more brains, the story might have been very different indeed" (Trachtenberg, 2000: 205). In his "Comment," Alan Sharp, in line with Nicolson's recollections, states that participants of the peace conference did not have a clear sight of what they wanted. The relatively sudden end of the war did not leave enough time to consider which war aim to put forward in both armistice and peace negotiations, and all these were further complicated by the respective tactics of the other allies (Sharp 1998). Allied insistence on German payments even had the capacity to seriously hurt the victors: Niall Ferguson pointed out that German payments could only be made in time after seriously devaluing the Reichsmark to gain a surplus in foreign trade - a move that in turn endangered the balance of payment of the victorious countries (Ferguson, 1998). The French, while insisting on defense and reparations for their own national interest, had probably the soundest strategy from Armistice Day up to the time of the negotiations. According to Soutou's study and Trachtenberg's analysis, the French did take into account the necessity to cooperate with Germany if the 'Anglo-Saxon' guarantee was not forthcoming to France. In fact, Clemanceau saw a possible and limited Franco-German cooperation as a potential bulwark against both Bolshevism and 'Anglo-Saxon' domination of the continent. Although the seriousness of a potential rapprochement with Germany in French thinking is still debated, Trachtenberg concludes that French policy resembled something like an early Gaullism (Soutou, 1998; Trachtenberg, 2000). Perhaps the most consensual part of the consensus was the resolute assessment that the failings of the Versailles treaty did not prescribe all the instability and horror that was to come in the interwar years: the rise of Fascism, economic nationalism, and bitter rivalries was not a predetermined consequence of the war (Boemeke et al., 1998; Trachtenberg, 2000; Marks, 2013).

By the time the latter views were established as a new scholarly consensus, Margaret Macmillan came out with her book Paris 1919. The Canadian historian, herself 
doi: 10.14267/cojourn.2019v4n2a1

a great-granddaughter of Lloyd George, offers a well-written account of the Paris Peace Conference, and more importantly, the origins and consequences of each regional issue that emanated from the war. Macmillan's book instantly rose to prominence and reached unseen popularity in this topic. Newer and newer editions came out, along with many translations. Macmillan, who is a professor of diplomatic history at the University of Oxford, is essentially seen as someone who mastered narrative history. Sally Marks, in her succinct critique of the book, pointed out some of the flaws that diplomatic historians tend to have with Macmillan's account: the conflation of chronological and topical parts, a tendency of story-telling, a colorful but somewhat misleading basis of sources, some unintended faults that could have been avoided with more careful proof-reading, and a tendency to omit assessment, especially regarding the 'lesser treaties.' Macmillan's major assertions actually follow the consensus established by the essay collection edited by Boemeke et al. Indeed, she did a great job in dispersing some of the most pervasive myths, i.e. that the treaty was in fact a 'Carthaginian peace'; that reparations were huge and necessarily led to the ruining of German democracy; or that the peacemakers were vindictive, revengeful and short-sighted. His assessment of Lloyd George is quite positive, but at the same time she also highlights English Francophobia and acts of restraint and moderation on the part of Clemanceau. She does admit that faults were made in Paris - especially regarding territories outside Europe-but the European peace was the fairest settlement to come out of the unfair conditions created by the war (Marks, 2001). The author blames procedural issues for the failings of the conference: too many topics, too much detail, too many things to decide in a disunited atmosphere. Her most original contribution is the emphasis on the classical education of the contemporary political class. Lloyd George knew more about the geography of the ancient Middle East than that of Europe; Nicolson considered the Greeks the most gifted people on earth, while he saw the Turks as the most notorious despots. As the claims were conflicting and as the negotiations were often lacking direction, many issues were finally decided by the authority of the peacemakers alone. In these cases, their classical education and sympathies proved to be decisive (MacMillan, 2001; also highlighted by Marks, 2001). MacMillan argues that Lloyd George did not know much about European geography but due to his religious education he was excellent in ancient names and locations in the land of Israel/Palestine. When he said that the borders should be stretching "from Dan to Beersheba," most of his contemporaries had to consult Biblical maps to cipher out the exact meaning of the Prime Minister's words (MacMillan, 2001: 415). Such one-sided 
doi: 10.14267/cojourn.2019v4n2a1

knowledge, unpreparedness, coupled with the utmost secrecy and a massive bureaucracy flooded with and blocked in trivialities, resulted in ad hoc decisions, including the phenomenon of reaching decisions for the sake of reaching them. This is one of the points John Lukacs is referring to as a major fault in the peacemakers' attitude at the conference (Lukacs, 2013: 33). According to Macmillan's reviewer, she wrote an excellent, though sometimes flawed account, which would help spread the historical consensus, but undoubtedly represents "an Anglo-American point of view, especially Anglo." Most of the new scholarly consensus represented, in turn, if not an Anglo-American, but a distinctively Eurocentric viewpoint-with the word Eurocentric used in a 'West European' sense.

The archives were furnishing evidence for scholarship in Eastern Europe as well. There was already something to build on: as early as 1966, Norman Stone, with his command of both German and Hungarian, wrote a piece on "Hungary and the July Crisis" with a clear analysis of the strategic choices of Count Tisza, the Prime Minister of Hungary, a person hitherto seen in indiscriminately negative light (Stone, 1966). From the 1960s on, F. R. Bridge wrote extensively about Austria-Hungary and its participation in the war (Bridge, 1972, 2016). William Godsey analyzed the Austro-Hungarian Foreign Office and how it worked on the eve of the First World War (Godsey, 1999). Stone later wrote a synthesis on the diplomatic and military history of the Eastern Front (Stone, 1998). István Diószegi’s Hungarians in the Ballhausplatz in 1983 provided an insight into Austro-Hungarian foreign policy but his grand synthesis of the same topic is unfortunately only available in Hungarian (Diószegi, 1983, 2001). Géza Jeszenszky, former Minister of Foreign Affairs, wrote a piece about how European countries perceived Hungary and 'Hungarianness' through time, but the volume Az elvesztett presztizs (Prestige Lost) is only available in Hungarian. Magda Ádám's The Versailles System and Central Europe is a well-researched and well-written study from an East European angle (Ádám, 2004) and it in fact had a greater international impact than most of the above mentioned.

\section{Empires strike back}

Early works which questioned the consensus came, in a somewhat surprising way, from postcolonial studies. These new ideas did not, however, seek to deconstruct the consensus altogether, but pointed out its Eurocentric nature. One of the old notions-namely, that the First World War brought about the end of empires and the universal victory of the 
doi: 10.14267/cojourn.2019v4n2a1

nation-state - was challenged by the pervasive imperial nature of the victorious powers. In fact, this postcolonial reinvigoration of Versailles historiography started out with studies on non-European combatants; then turned to a reassessment of national selfdetermination on a global scale, and questioned the structural significance of the peace settlement.

John H. Morrow, in his chapter "The Imperial Framework" in The Cambridge History of the First World War, argued that the unseen brutality and the claim to totality was but an application of colonial warfare on European soil. He traces back wartime annexationism and economic warfare to the amplification of imperialism before 1914. He further adds that European youth "literally yearned for war," which had its root in Darwinism, pan-German and pan-Slavic ideas, as well as in what we might term 'resilience movements' emanating from the dearth of memories of European unpreparedness in the late-19th century colonial uprisings. Bringing back the ferocity of colonial warfare to Europe was apparent in the application of airplanes and dum-dum bullets - hitherto banned in other than colonial warfare. The 'introduction of savage war' was further underlined by the introduction of colonial troops: using the force noir on European soil not only instilled fear in the hearts of enemies, but also generated concerns about the fate of European civilization at home (Morrow, 2014: 405-413). Imperialism thus provided a source of inspiration, the means of fighting, and war aims. As Jane Burbank and Frederick Cooper succinctly summarize, "It was empire that made the Great War a world war" (Burbank-Cooper, 2019: 85).

Once again considered an 'imperialist war', it is surprising to claim that the peace settlement signaled the advent of the age of 'nation-states.' The idea that the Versailles system did away with empires and cemented the norm of nation-state, contributing to the decline of worldwide imperialism is so common that it is actually one of the diehard WWI topoi (Manela, 2007: 5; Dannreuther, 2013: 96-97). It is true that the raging imperialist war presented a legitimacy deficit for empires, and the fact that even the victorious empires faced increasing pressure and resistance in the aftermath of war. However, as most colonial troops showed loyalty, and most local leaders supported the home front, the claim of 'civilized' and 'civilizing' empires led to a stabilization of colonial control for those on the winning side (Burbank-Cooper, 2019: 81-86). On the other side of the spectrum, self-determination-selectively used in Europe-was altogether denied to colonial peoples. Moreover, some of the decision-makers warned against propagating 
doi: 10.14267/cojourn.2019v4n2a1

self-determination with a view to the possibly detrimental effect on the colonies (Burbank-Cooper, 2019: 91).

Another important issue raised by this type of scholarship was the origin of selfdetermination. It was set forth by Lenin in his 1916 "The socialist revolution and the right of nations to self-determination," but it subsequently came to define and symbolize the American approach to peace. Even though the normative anti-imperialism of the U.S. is well-known, this is not an obvious outcome for a war involving empires. Its roots indeed run deeper: to the allied war aims, German diplomacy in the year 1918, the disruptive effect of the Bolshevik revolution on the war, and the internal hardships of the failing Eastern empires. First, one of the original British war aim was the salvaging of Belgiuma tiny neutral country that had fallen prey to the German war machine - and the idea to 'protect' the weaker nations. It has become part of Allied self-legitimacy and propaganda even as it lost some of its credibility with the Allied breach of Greek neutrality in 1917 (Soutou 502-503). Wilson's first addresses did not reveal a commitment to breaking up empires and supporting breakaway nationalities. On February 11, 1918 he claimed in Congress that "this war had its roots in the disregard of the rights of small nations and of nationalities which lacked the union and the force to make good their claim to determine their own allegiances and their own forms of political life" (qtd. in Leonhard, 2017: 330). It was in fact Germany who first raised the idea of self-determination to prominence: in the dual treaties of Brest-Litovsk, self-determination became the ultimate basis that provided for the withdrawal of Russia to the East, and the heavily pro-German independence of Ukraine. Bolshevik Russia needed the demonstration of German power to follow this legalistic argument, but the Bolsheviks finally had to give in. It was thus this moment in early 1918 when self-determination made its way from the saloons to the negotiating tables (Chernev, 2011). By this time, pure annexationism had faded away as a war aim: both sides wanted to create an economic order that is minimally legitimate for those under their sway, while serving their imperial interests as it does not necessarily require active policing of the territories concerned (for the economic outlook in peace designs, see: Soutou, 1989 and 2014). Notice that Lenin's ideas about anti-annexationism generated waves of enthusiasm on the European and American Left, the net result of which was a "decisive left turn" in war aims and rhetoric (Anievas, 2014: 638).

It was again Germany who-following the failure of the Michael Offensiveinvoked 'Wilsonian principles' for the foundations of an armistice. The impossibility of a compromise peace became apparent in 1918 and it was Germany-out of necessity- 
doi: 10.14267/cojourn.2019v4n2a1

who invoked the idea to put the peace negotiations on the basis of a wholly new international approach. Even if the Fourteen Points-still not putting forward the inevitable breaking up of empires-became instantly popular in North American and European public opinion, and was even praised by Lenin, the Allied governments were anything but enthusiastic (Knock, 1998: 115). Contrary to widely held beliefs, the Eastern empires were not doomed from the outset because of their internal weaknesses: the German Reich was not weak at all, Russia was able to transform itself into the Soviet Empire, recuperate its former territories and more. It was often said, however, that Austria-Hungary was so fatally feeble by this time that it dispersed rather than was dissolved. On the other hand, many claim that there was nothing inevitable about the unravelling of Austria-Hungary (Zimmer, 2013).

According to the oft-cited paraphrase, the U.S. wanted to make the world "safe for democracies." What democracy meant in America by this time was almost equivalent with the opposite of empire - a political community that is united by manners and aims, within fix geographical borders, whose people are-for the most part-able to choose their type of government. The American idea, rooted in a national, federalist understanding of polity, could scarcely have been applied to a European, let alone an East European, context. In fact, when applied to the complex realities of ethnic, national, and traditional loyalties in Eastern and Southeastern Europe, the idea of self-determination was quite different than what was imagined in the U.S. or in Western Europe (Leonhard, 2017: 330, 341). War's end saw a public perception that nation-states were dynamic and modern, able to harness the creative energies of whole nations; and that they combined external strength with internal unity. On the other hand, empires were seen as outdated, and doomed to fail because of their diverging levels of loyalties, heterogeneity and lack of common purpose (Leonhard, 2017: 331, 341). Given the complex ethnic and religious map of the region, the creation of nation-states inevitably gained an ethnic character (Keylor, 1998: 476), required intensive nation-building processes, and what is now often termed as the "de-mixing" or "unmixing of peoples" in order to reach a degree of national unity. In fact, both liberals, primarily interested in nation-building, and reactionaries, with their sharpened sense of nationhood, accepted the idea of radical population transfers to reach this goal (Burbank-Cooper, 2019: 90-92). This 'unmixing' of people was already underway before 1914, as was demonstrated during the Balkan Wars, but it undoubtedly became more widely accepted after Versailles. Contrary to the presupposed idea, these nation-states were thus not truly unitary inside. The net result of all this was, as Jörg 
doi: 10.14267/cojourn.2019v4n2a1

Leonhard puts it, that "If there was a triumph of the model of a homogeneous nationstate, it was more and more dissociated from the democratic principle in practice" (Leonhard, 2017: 344). This is one of the cornerstones of a particular historiographical reassessment: empires are increasingly less seen as inevitably failing and as being by nature oppressive by the 1910s. Rather, as an organizational form of the state that is more willing and more successful in accepting internal differences than nation-states are (Burbank-Cooper, 2019: 85). In fact, one may argue that Wilsonism was designed to "make the world safe for democracies," but eventually led to a European order that was safe for nationalism. Democracy, applied to the East European environment, exacerbated nationalism that in turn did not reinforce democracy. The international environment promoted, supported, and rewarded the idea of the nation-state, while the example of Turkey showed that a turn to being nation-state can lead to complete integration into the Versailles order.

As identity issues came to the forefront in the 2000s, it reached the study of both the Great War and the Versailles settlement: how sovereignty and political legitimacy were created and represented during the wars became a major theme (Payk-Pergher 2019). Minor identities and contradictory loyalties were highlighted: people from AlsaceLorraine were examined, either their captivity in Germany for perceived disloyalty, or when drafted into the German army 'against their will' (malgré eux) (Sawicki, 2017; Minasian-Kaneeva, 2017). Timothy Baycroft dealt with identities and nation-building efforts in French Flanders (Baycroft 2004). The experience of Poles, serving in the armies of three empires, is particularly interesting (Latawski, 1992). Lucian Boia wrote about the Romanization of Romania (Boia, 2015), pointing to the complex dynamic of being Romanian, Hungarian, and Transylvanian in a state embarked on nation-building. In Greece, the different interpretations of nationalism - an expansionist new, and an introverted old nationalism — was identified as a major source of the National Schism (Mavrogordatos, 2014). The "unmixing of peoples" was pronounced in most new nationstates - whether successor states or former empires. The lost, vibrant multiculturalism of the Hungarian capital was vividly described by John Lukacs (Lukacs, 1988). All of the above were attempts at crossing the binary lines of victors and vanquished, along with national histories and identities, pointing out the much more complex and shifting realities that were present during and after the war, and bearing serious consequences for the future settlement of Europe. 
doi: 10.14267/cojourn.2019v4n2a1

While the Paris Peace Conference was intent on making a 'world order', there was not much order in the following years. There was a widespread feeling of "dual disillusionment", a general disappointment in the ideas of international order itself, as well as those of domestic orders. Wilson knew that his visions raised expectations to a level where disillusionment was an inevitable consequence: "When I gave utterance to those words [on the right to self-determination], I said them without the knowledge that nationalities existed, which are coming to us day after day [...] You do not know and cannot appreciate the anxieties that I have experienced as a result of many millions of people having their hopes raised by what I have said" (Leonhard, 2017: 344).

This did not usher in a period of peaceful international relations. Rather, it resulted in bitter conflict, mutual suspicion, and conflicting nationalisms in Europe (BurbankCooper, 2019: 82). The cherished introduction of collective security and multilateral diplomacy could not deliver: instead, the fear of competing nationalisms, revisionist standings, and a general lack of faith in anything other than national strength led European countries to instantly revert to bilateral security treaties (Leonhard, 2017:344). This could have been averted if there was a credible guarantee of international order behind the Versailles settlement, but neither Wilson, nor Lloyd George seriously thought about that. Instead, they imagined to redress the continental balance whenever threatened by either power (cf. Trachtenberg, 2000: 197-200). As Egerton pointed out in 1978, the British accepted the idea of the League of Nations as a pool in which American capacities would be joined with theirs, and from which position they could arrange the unevenness of the European balance and keep control of colonial territories. After the withdrawal of the U.S. became apparent, the British were also considering to leave the League of Nations for the fear that administering a liberal international order would be too much of a burden, as they would not be able to uphold the balance of power without the Americans (Egerton, 1978: 889-897). Some of the treaty's most characteristic features were drafted in the belief that the Americans were there to remain: it was the Americans and the British who demanded the entire sum of reparations from Germany, not the French. They thought that American banking would provide for a moderate means to collect it. While the reparations were by no means as harsh as their fame, their sum was calculated according to the American presence (Keylor, 1998: 498-502; Trachtenberg, 2000: 194, 197-198). The problem of the missing American underpinnings of the peace settlement was obvious from almost the beginning: from the proposed Geneva Protocol, to multiple French attempts to broker an alliance with the U.S., and to the Locarno Treaties, much of the 
doi: 10.14267/cojourn.2019v4n2a1

interwar years' diplomacy was about shoring up the Versailles order. The British soon realized that the U.S. is only an onlooker in European affairs, while the anti-revisionist powers lack the means to defend the system (Lojkó, 288-290).

Shortly before leaving the conference, Vittorio Orlando, Italian Prime Minister at the Paris Peace Conference, summarized the most serious deficiency of the peace treaties: "I cannot look forward without grave apprehensions to the future of continental Europe; the German longing for revenge must be considered in conjunction with the Russian position. We can thus see even now that the settlement to be arrived at will lack the assent of more than half the population of the European continent. If we detach from the block on which the new European system will have to rely for the support of forty million Italians, and force them into the ranks of the malcontents, do you think that the new order will rest on a firm basis?" (Butler, 1968: 226) The settlement thus quickly became unpopular and illegitimate for many-no one seriously wished to maintain it, while everyone saw its faults that came in strong contrast with the lofty declarations behind it (Leonhard, 2017: 340-343). The sense of disappointment and anger was probably even more pronounced amongst the elites of countries under colonial or semi-colonial rule. The Japanese, who did not succeed in cementing their position as a major power, or the Chinese, whose interests were almost altogether ignored, or the Indians, whose status did not budge, and all the people who cherished "self-determination" as a prospective way out of colonial rule, were bitterly disappointed and alienated from the Versailles settlement (Xu, 2014: 506-509).

\section{Reconfiguration of the Global Balance of Power}

Another cautious recognition emanating from postcolonial studies was the assumption that the war did not fully end in 1918 and did not start in earnest in 1914. As Gerwart and Manela concludes, the First World War was an all-out war between empires who started a cycle of violence already in 1911 with the Italian occupation of Libya. The spillover effects of the colonial war were felt during the Balkan Wars and then in the Great War, only to recede after the Treaty of Lausanne, the end of the Franco-Belgian occupation of the Rhineland, the granting of independence to Ireland, the Bolshevik victory in the Russian Civil War, and the reconfiguration of power in East Asia (Gerwart-Manela, 2014: 688-695). Already in 1995, Felipe Fernández-Armesto pointed out that the First World War was essentially but “an umbrella term” (Fernández-Armesto, 1995: 417). The 'continuation of violence' and the 'long ending' of the First World War are major 
doi: 10.14267/cojourn.2019v4n2a1

concerns of historians since the 2010s. This new focus is well demonstrated by the fact that Alan Sharp's 1991 synthesis once bore the subtitle "Peacemaking in Paris, 1919", while the third edition, coming out in 2018, was titled "Peacemaking after the First World War, 1919-1923” instead (Sharp, 1991 and 2018). French historiography has focused on 'the exiting from war' (sorties de guerre), i.e. demobilization, reintegration, or the lack thereof, veterans' issues, etc. (Flateau, 2016). International aid missions in the aftermath of the war are also of particular significance (Glant-Ablonczy-Juhász 2018). Refugees coming from successor state territories and the impact of Bolshevism and the 'continuation of violence' are also in the focus of the new historiography, such as in the work of the Trianon 100 research group (Ablonczy, 2010; Ablonczy, 2017; Révész, 2017). Connected to the centenary of the Great War, this 'long ending' by now has become an integral part of researching WWI - an approach actually more widely held in Eastern Europe (cf. Schmidt 2019). This 'continuation of violence' found expression in the most modern scholarship of the Great War with a focus on the brutalizing effect of the war, paramilitary organizations in the East and the West, and their detrimental impact on interwar Europe: scholars have examined the situation on a European and also on a global scale (Geyer, 1989; Gerwarth-Horne, 2010; Gerwarth, 2008) as well as at the level of particular countries, such as Turkey (Gingeras 2010). A cornerstone of centennial commemorations and research agendas is inquiry about veterans' issues, their reintegration into society, their associations, and their politicisation (Mission Centenaire, 2019; First World War Centenary, 2019; Trianon 100, 2019). The net result of this renewed interest was the emerging consensus that the deterioration of political culture in interwar Europe, the rise of Fascism and the expansion of Communism was not a 'direct result' of the Versailles settlement but an offshoot of the brutalizing effect of the Great War. Already in the early 1920s Mussolini envisioned the rule of trenchocracy, i.e. the rule of those returning from the trenches. This, of course, never really materialised, but both Fascism and Communism actively built on the war experiences, the general resentment war caused, the heightened status of the state, and the devaluation of human lives. In a sense, states were becoming warfare states and welfare states at the same time during the war-owing to the transformative effect of the Herculean task of mobilization and economic planning - and they remained so well after 'Armistice Day' (cf. Horne, 2014: 628-634).

The 'continuation of violence' was indeed a reverberation of the fact that the Versailles settlement could not truly settle the problems that fueled the Great War. When 
doi: 10.14267/cojourn.2019v4n2a1

Germany decided to put down arms the situation was not like that of 1945. Conclusive military victory was not in sight. Germany, in spite of all of its setbacks, was still potentially the most powerful country on the continent (Marks, 2013: 655). Though the Habsburg, Ottoman, and Russian Empires crumbled and underwent serious changes in the aftermath of war, Germany was largely intact, and there was no foreign occupation.

The normative nature of 'defeat', the exclusion of Berlin from the crucial points of the settlement, coupled with German power that was shaken but not broken, led to a situation where the Reich was there to remain one of the most powerful countries after the war. Britain and France, ravaged and exhausted in war, facing colonial upheaval and financial difficulties, were in the role of victors but could not hold on to their power indefinitely. In fact, the true power relations were not clear at the table - as was amply demonstrated by Anglo-French conflicts, Italy's disappointment, the illusion of Greek power, the illusion of Turkish weakness, and overall, everyone's attempt at manipulating Wilson. In a sense, the reshaping of East Europe was of secondary importance throughout the conference. The Paris Peace Conference, above all, can be perceived as a West European lobbying conference. Thus, the established scholarly consensus about the relative soundness of peacemakers and of the settlement (as in Tanner, 2004; Keylor, 1998) is truly applicable only if Versailles is considered as a peace with Germany, or a peace settlement between the Eastern and Western halves of Europe. No lasting international order was set up, a great many conflicts were essentially halted only as late20th century 'frozen conflicts' would be in the future, imperial issues were mounting, and most of the world - as well as most of Europe - did not see itself as a stakeholder in maintaining the settlement. Ironically, the settlement might have been good enough to settle a war with Germany - but definitely not to settle a world war; although the 'dark legend' of Versailles for decades has been focusing on the maltreatment of Germany.

Another often overlooked factor of the peace settlement was the wholesale devaluation of Europe as the center of world politics and the world economy. John Horne quoted the French poet Paul Valéry: "We modern civilisations [like those of antiquity] now know that we too are mortal." Europe, as ancient Greece before it, ceased to be the crux of world affairs, or so this was perceived. Such an assessment was easily seen in the culture of the interwar years: Oswald Spengler's The Decline of the West was published in 1918; T. S. Eliot's war-inspired modernist poem The Waste Land was out in 1922, while Ortega y Gasset's The Revolt of the Masses in 1929. Cultural relativism established itself in academia and in public consciousness - a development unimaginable before the 
doi: 10.14267/cojourn.2019v4n2a1

war (Fernández-Armesto, 1995: 483-485). John Lukacs repeatedly pointed to the rise and decline of the liberal bourgeoisie and its impact. According to him, the most important and pervasive feeling after the war was the devaluation of middle class virtues and manners, and the outright denial thereof, as was manifest in Spengler's work (Lukacs, 2013: 33-40). Europe's decline as cultural and political center is also a major theme in the newer historiography of WWI that employs powerful imagery. Christopher Clarke's superb account about the outbreak of the war is titled Sleepwalkers referring to the shortsightedness of pre-war statesmen as he attributes 'war guilt' to all of the major parties. Sean McMeekin, in his The Russian Origins of the Great War, stresses the importance of Russia's imperial design in the outbreak of the war. He even claims the Great War to have been "the Ottoman War of Succession", with a fair degree of convincing power. The fact that Europe was losing ground was apparent in culture but not in politics, however. The reconfiguration of power was not according to the present or projected power relations but in many cases obscured by aggravated perceptions, expectations, and a 'culture of defeat.' As John Horne puts it: “... the scale and repercussions of the displacement [of power] were masked in the interwar period by the relative effacement of the two states, the USA and the USSR, which would redefine world power in bi-polar terms after a further round of European self-destruction in 1939-45" (Horne, 2014: 634). This feature of 'being masked' is also implied by some of the alternative labels that exist for the Great War, as in "the hundred years' war of Europe" (referring to the whole of the 20th century), or in "Greater War", referring to the period from 1911/1914 to 1923. The underhanded power shift among great powers, blurred by normative politics and tradition, led to a questioning of both the contours and the outcome of the war (cf. Schmidt, 2019).

The U.S., on the other hand, was clearly an ascendant power. This phenomenon was also masked to a certain extent by the inextricable web of power dynamics during the Paris Peace Conference. The extent to which American ideas could transcend European politics was a question of European resistance. It is surprising, however, how both liberal apologists and conservative critiques both accepted the notion that the Americans were truly idealist, for better or worse (Anievas, 2014: 620). In fact, the idea that American idealism was a diametrical opposite to realist balance-of-power thinking was pervasive over decades of scholarship. For instance, Henry Kissinger takes idealism vs. realism as the central issue in Wilsonism — although he skillfully distinguishes idealist rhetoric and the realist assessment around the formation of NATO in 1949 (Kissinger, 1994; Kissinger, 2012). It was relatively late when a major thesis emerged to the effect 
doi: 10.14267/cojourn.2019v4n2a1

that Wilsonism might be perceived as realist self-interest wrapped in idealist rhetoric, and that idealism in fact served tactical national interests (Ninkovich, 1999; Kennedy, 2008; Anthony, 2008).

As the historiography of American foreign relations underwent some changes and 'Republican empire' became a major area of interest (Lafeber 1993; Weeks 2013), American idealism and its implications were also increasingly looked upon in a different light. Even though Akira Iriye interprets the interwar years in a positive and nonimperialist framework, the title of his book The Globalizing of America, 1913-1945 (Iriye, 1993) points to the fact that 'American isolationism' is not the right framework to address U.S. foreign policy in the interwar years. In fact, isolationism was a fair rhetoric on the side especially of those American politicians who represented constituency that was not involved in international trade (Nazirny, 2003), but actually both Wilsonians and fierce critiques of Wilson apprehended the changing role of the U.S. that had to follow WWI. What was debated, however, was "what type of internationalism" to choose: active or passive, interventionist or 'isolationist', diplomatic or commercial. Supporters of Theodore Roosevelt were no less internationalists as Wilson was, but they perceived the role of the U.S. differently (Condra, 2018).

Anievas, while accepting the idealist side of the coin, asserts that liberal internationalism was persistently conceived in "terms of serving narrowly defined US national interests - above all, the pursuit of US global supremacy" (Anievas, 2014: 625). U.S. national interests, given that for a long century North America has not been credibly threatened by outside powers, was first and foremost commercial: freedom of the seas and of trade. For Wilson - and many of his contemporaries - it was inevitable that "the East" open up and transform, and it was up to America and Britain to govern and master this transformation. The expansion of U.S. capital and liberal American ideas were mutually reinforcing. The United States, after all, was the "city upon a hill," a model for the rest of the world. What was strikingly different in U.S. and European expansionism was of course the non-territoriality of the former. Washington was aiming at the expansion of capital, culture, and trade on equal terms with the European powers - the globalization of "Open Door policy." 'Backward' territories would eventually develop into decent countries with the help of American technology, ideas, and money. The remedy for war, destruction, backwardness, and international selfishness was thus an 'intracapitalist understanding' about the mutually acceptable management of world affairs. This propelled the League of Nations - originally an idea of the British Left — to 
doi: 10.14267/cojourn.2019v4n2a1

paramountcy in Wilson's ideas. The Bolshevik menace, as well as the vindictive Treaty of Brest-Litovsk changed expectatons: Germany was, for the time being, dispensed from the advanced capitalist countries which were to form an international framework; and Bolshevik ideas of revolution necessitated a liberal response that was attractive for the European Left. Not an American contempt towards Empires, but the Bolshevik challenge caused the left turn in American vision that resulted in the championing of selfdetermination. The difference was substantial: while Lenin sought to facilitate revolution with self-determination, Wilson wanted to build it up as a bulwark against radicalism and revolution (Anievas, 2014: 627-642; Keylor, 1998: 471-472; Manela, 2007: 39-43). Anievas in his convincing analysis argues that while the idealist framework was not a mere smokescreen, liberal internationalism was another side of liberal empire, where racially hierarchal, development-driven crisis resolution can serve the interests of a world whose interests were deemed identical to U.S. national interests (Manela, 2007: 626$627)$.

The Versailles settlement, of which the leading impulse was coming from the U.S. as the great creditor nation for both sides, was one of the first steps in the quest to global supremacy. In order to globalize America, the most important issue to deal with was in fact the role of Britain and the second was the issue of the remaining European powers. Bottelier argues that the Great War destroyed "gold standard and the first globalization", and Britain, as the main architect and beneficiary of both, lost its status (Bottlier, 2017: 5). The fact that the 'golden age' of the British Empire was over came through clearly to many: influential persons close to Lloyd George have long argued for a federal restructuring of the Empire, to better match power relations within its confines, and to create the possibility of merging with the U.S. at some future time. Federalism, an imperial answer to preserve both unity and difference was seen as a "way out of empire" (Burbank-Cooper, 2019: 83, 99) but the Round Table circle went even further: they wanted to make the inevitable process of translation imperii a swift and painless one by achieving the maximum of Anglo-American cooperation (Roberts, 2006; D'Onofrio, 2019). However, even though a high degree of cooperation was reached by London and Washington, the non-ratification of the treaty and the 'abandonment' of Europe caused a bitter readjustment of British policy (Egerton, 1978). On the other hand, the longer term processes of the American overtaking of oil, telecommunication, and aviation industries was underway since the Paris Peace Conference (Hugill, 2009). The Washington Naval Conference in turn sealed Britain's traditional role in policing and controlling the high 
doi: 10.14267/cojourn.2019v4n2a1

seas: they did relinquish some of their freedom in naval issues and accepted their secondary role in the Pacific in order not to frustrate the possibility of a later AngloAmerican cooperation (Goldstein, 1993). If real power relations were, according to Horne, masked during the Paris Peace Conference, so was the exact nature of relations between the most advanced industrial and naval nations, Britain and the U.S. The power transition between the two, and its motivations and repercussions are not completely new spots on the research agenda, but their centrality is a major development.

Similarly important was the wholesale Americanization of European politics and culture. American standards, rhetoric and political philosophy was thriving on the old continent, and found its expression in the arts, in popular taste, and in finances. International finances, dominated by the U.S., were of particular importance: the "depoliticization of international economies" (Anievas, 2014: 632) was underway. The cultural impact of the U.S. was paramount in Western Europe, especially in Germany. As F. Scott Fitzgerald put it, the Americans were going to be the Romans, as were till then the British (Costigliola, 1985: 18-22, 167-169, 177). The League of Nations, though dysfunctional in many ways, was after all an American design. The leading tenets of nonFascist European politics, nationalism, disarmament, the primacy of stability and commerce, and the expanding vision of self-determination were all American imports. During the days of the war, Wilson himself prophesied: "When the war is over, we can force them [the Entente powers] to our way of thinking" (Fernández-Armesto, 1995: 419). The liberal American Empire was, in a sense, idealistic; but its more tangible feature was its pragmatism.

\section{Conclusion}

The study of the Versailles peace settlement well illustrates that historiography evolves according to the accessibility of sources and also the impressions of contemporary interpretations. The earliest historiographical debates revolved around the harshness of the treaty with Germany (but not necessarily with the minor members of the Central Powers), the war guilt clause and the diehard classic of who started the war; as well as the transition from the settlement to the rise of Fascism and beyond.

A closer scrutiny of the papers in the 1960s pointed out the relative moderation of the French; the exact nature of the war aims and their effects on peacemaking; a closer look at the relationship between Leninism and Wilsonism; and the debunking of the "war 
doi: 10.14267/cojourn.2019v4n2a1

guilt myth'. The result of this was a more moderate and unbiased assessment of Versailles with occasionally too lenient undertones.

This new consensus, partly popularized by Macmillan's exquisitely written book, was increasingly questioned when contemporary political issues renewed interests in issues of empires vs. nation-states, sovereignty and integration, and the fate of American hegemony. This impulse originally came from postcolonial scholars and it changed how we see the Versailles settlement on a global scale. It exposed that Versailles was a European peace to settle a world war; that emotional and political dissociation from the treaties in Europe actually killed its chances of success; that the continuation of violence and the blurred lines of new power structures questioned the nature of the settlement which had mostly a freezing effect on international conflicts; that the rule of the liberal bourgeoisie and their manners were essential in the postwar vision; that new nation-states were becoming imperial, while empires were becoming more akin to nation-states; that the nostalgia for dissolved empires had contributed to ideas of European integration; and that American isolationism might refer to politics but definitely not to international economy.

The history of the Versailles settlement is immensely important as a major cornerstone in 20th century history and a departure point for the study of international relations. A transnational and global history was unfolding in the 2010 s with increasingly more differentiated sources and viewpoints added to the analysis. What is still missing from the picture is the inclusion and comparative analysis of Eastern European views, narratives, and impulses. Postcolonial scholarship propelled China, India, African colonies, etc. into a central position, but still, Western accounts of the settlement often appear without a reference to Eastern Europe, or are only paying marginal attention to the region. This is partly due to the nature of East Europe, with its small and inaccessible languages, the failure of the societies concerned to link national to global histories, and the socially and politically contested nature of the topic that serves as an excellent experimental diorama for the 'politics of memory.' Some of the minor treaties are underresearched due to being overshadowed by subsequent events (such as the Treaty of Neuilly-sur-Seine), or dealt with in different frameworks (such as the Treaty of Trianon, Saint-Germain-en-Laye, or Sèvres). Partly because of the concurrent nationalisms and biased historiographical approaches, partly for lack of interest, international historiographies thus do not accentuate the relevant questions regarding Eastern Europe. The process of linking 'forgotten evidence' from Eastern Europe to the global picture has 
doi: $10.14267 /$ cojourn.2019v4n2a1

started, nonetheless (see e.g. Stone, 1998; McMeekin, 2013; Chernev, 2011), but there still is a long way to go to reach a truly global assessment of the Versailles peace settlement.

\section{References}

Ablonczy Balázs (2010): Trianon-legendák. Jaffa Kiadó, Budapest, 2010.

Ablonczy Balázs (2017): Rettenetes év. A párizsi békekonferencia és Magyarország, 1919-1920. Rubicon (29) 7-8. pp. 4-13.

Ádám Magda (2003): The Versailles System and Central Europe. Ashgate Publishing Company, London, 2003.

Ambrosius, Lloyd E. (1977): The Orthodoxy of Revisionism: Woodrow Wilson and the New Left. Diplomatic History (1) 3. pp. 199-214.

Anievas, Alexander (2014): International relations between war and revolution: Wilsonian diplomacy and the making of the Treaty of Versailles. International Politics (51) 5. 619-447.

count Andrássy, Gyula: Diplomacy and the War. John Bale, Sons \& Danielsson, London, 1921.

Anthony, C.G. (2008): American democratic interventionism: Romancing the iconic Woodrow Wilson. International Studies Perspectives (9) 3. 239-253.

Baycroft, Timothy (2004): Culture, Identity and Nationalism. French Flanders in the Nineteenth and Twentieth Centuries. Woolbridge, 2004.

Birdsall, Paul (1941): Versailles Twenty Years After. Reynal \& Hitchcock, New York.

Boemeke, Manfred F.-Feldman, Gerald D.-Glaser, Elisabeth (eds.): The Treaty of Versailles. A Reassessment after 75 Years. Cambridge University Press, Cambridge.

Boia, Lucian (2015): Cum s-a românizat România? Editura Humanitas, București, 2015. Bottom, William P. (2004): Essence of Conflict. Cognitive Illusions, War Guilt, and the Origins of Appeasement. John M. Olin School of Business Washington University in St. Louis. <http://apps.olin.wustl.edu/workingpapers/pdf/2004-07-001.pdf > Accessed: April 12, 2019

Bridge, F. Roy (1972): From Sadowa to Sarajevo. The Foreign Policy of AustriaHungary, 1866-1914. Routledge--Kegan Paul, London--Boston, 2002 [1972].

Bridge, F. Roy (2016): Sir Edward Grey and Austria-Hungary, The International History Review, (38) 2. pp. 264-274. 
doi: 10.14267/cojourn.2019v4n2a1

Burbank, Jane-Cooper, Frederick (2019): Empires after 1919: old, new, transformed. International Affairs (95) 1. 81-100.

Butler, Rohan (1968): The peace settlement of Versailles 1918-1933. In: Mowat, C. L. (ed.): The New Cambridge Modern History. Vol. 12: The Shifting Balance of World Forces, 1898-1945. Cambridge University Press, Cambridge, 1968. pp. 209-241.

Chernev, Borislav (2011): The Brest-Litovsk Moment: Self-Determination Discourse in Eastern Europe before Wilsonianism. Diplomacy \& Statecraft (22) 3. pp. 369387.

Dannreuther, Roland (2013): International Security: The Contemporary Agenda. Polity Press, Cambridge, 2013.

Diószegi István (1983): Hungarians in the Ballhausplatz. Studies in the AustroHungarian Common Foreign Policy. Budapest: Corvina Kiadó, 1983.

Dockrill, Michael L.- Steiner, Zara (1980): The Foreign Office at the Paris Peace Conference in 1919. The International History Review (2) 1. 55-86.

D'Onofrio, Alessandro (2019): Laying the Foundations of the New World Order: The Round Table Movement at Versailles. Corvinus Journal of International Affairs (3) 4. In this issue.

Ferguson, Niall: The Balance of Payments Question: Versailles and After. In: Boemeke, Manfred F.-Feldman, Gerald D.-Glaser, Elisabeth (eds.): The Treaty of Versailles. A Reassessment after 75 Years. Cambridge University Press, Cambridge.

Fernández-Armesto, Felipe (1995): The Millenium. A History of the Last Thousand Years. Bantam Press, London, 1995.

First World War Centenary (2019). <https://www.gov.uk/government/topicalevents/first-world-war-centenary > Accessed: 14 April, 2019

Flateau, Cosima (2016): Les sorties de guerre. Une introduction. Les Cahiers Sirice (17) 3. 5-14.

Freud, Sigmund--Bullitt, William C. (1969): Thomas Woodrow Wilson: A Psychological Study. Houghton Mifflin, Boston, MA, 1967.

George W. Egerton (1978). Britain and the 'Great Betrayal': Anglo-American Relations and the Struggle for United States Rati $\square$ cation of the Treaty of Versailles, 19191920. The Historical Journal (21) 4. pp. 885-911. 
doi: 10.14267/cojourn.2019v4n2a1

Gerwarth, Robert (2008): The Central European Counter-Revolution: Paramilitary Violence in Germany, Austria and Hungary after the Great War. Past \& Present (200) 1. pp. 175-209.

Gerwarth, Robert-Horne, John (2010): The Great War and Paramilitarism in Europe, 1917-23. Contemporary European History (19) 3. pp. 267-273.

Gerwarth, Robert--Manela, Erez (2014): The Great War as a Global War: Imperial Conflict and the Reconfiguration of World Order, 1911-1923. Diplomatic History (38) 4. 786-800.

Geyer, Michael (1989): The Militarization of Europe, 1914-1945. In: Gillis, John (ed.): The Militarization of the Western World. Rutgers University Press, New Brunswick, NJ, 1989.

Gingeras, Ryan (2010): Beyond Istanbul's 'Laz Underworld': Ottoman Paramilitarism and the Rise of Turkish Organised Crime, 1908-1950. Contemporary European History (19) 3. pp. 215-230.

Glant Tibor-Juhász Balázs-Ablonczy Balázs (2018): Nemzetközi segély- és segítőakciók a volt Osztrák-Magyar Monarchia területén (1918-1923). Századok (152) 6. pp. 1321-1352.

Godsey Jr., William D. (1999): Aristocratic Redoubt: The Austro-Hungarian Foreign Office on the Eve of the First World War. Purdue University Press, West Lafayette, IN., 1999.

Goldstein, Erik (1993): The Evolution of British Diplomatic Strategy for the Washington Conference. Diplomacy \& Statecraft (4) 3. 4-34.

Graham Fry, Michael (1998): British Revisionism. In: Boemeke, Manfred F.—Feldman, Gerald D.-Glaser, Elisabeth (eds.): The Treaty of Versailles. A Reassessment after 75 Years. Cambridge University Press, Cambridge.

Horne, John (2014): The Great War at its centenary. In: The Cambridge History of the First World War. Vol 3: Civil Society. Cambridge University Press, Cambridge, 2014.

Irish, Tomás (2016): Peace through history? The Carnegie Endowment for International Peace's inquiry into European schoolbooks, 1921-1924. Journal of the History of Education Society (45) 1. 38-56.

Kennan, George F. (1961): Russia and the Versailles Conference. The American Scholar (30) $1.13-42$. 
doi: 10.14267/cojourn.2019v4n2a1

Kennedy, Ross A. (2008): The Will to Believe: Woodrow Wilson, World War I, and America's Strategy for Peace and Security. The Kent State University Press, Kent, $\mathrm{OH}$.

Keylor, William R. (1998): Versailles and International Diplomacy. In: Boemeke, Manfred F.-Feldman, Gerald D.-Glaser, Elisabeth (eds.): The Treaty of Versailles. A Reassessment after 75 Years. Cambridge University Press, Cambridge.

Keynes, John Maynard: The Economic Consequences of Peace. London, MacMillan and Co.

Kissinger, Henry A. (1994): Diplomacy. Simon \& Schuster, New York.

Kissinger, Henry A. (2013) [1954]: A World Restored: Metternich, Castlereagh and the Problems of Peace, 1812-22. Echo Point Books \& Media, New York.

Kissinger, Henry A. (2014): World Order. Penguin Books Ltd., New York.

Knock, Thomas J. (1998): Wilsonian Concepts and International Realities at the End of the War. In: Boemeke, Manfred F.-Feldman, Gerald D.-Glaser, Elisabeth (eds.): The Treaty of Versailles. A Reassessment after 75 Years. Cambridge University Press, Cambridge. 111-129.

Latawski, Paul (1992): The Reconstruction of Poland, 1914-23. Palgrave Macmillan UK, London, 1992.

Lenin, V. I.: The Tasks of the Third International. 14 July, 1919. Marxist Internet Archive. <https://www.marxists.org/archive/lenin/works/1919/jul/14.htm > Accessed: June 1, 2019

Leonhard, Jörg (2017): The End of Empires and the Triumph of the Nation-State? 1918 and the New International Order. In: Planert, Ute-Retallack, James (eds.): Decades of Reconstruction. Postwar Societies, State-Building, and International Relations from the Seven Years' War to the Cold War. German Historical Institute--Cambridge University Press, Cambridge, 2017.

Lepsius, Johannes-Mendelssohn Batholdy, Albrecht-Thimme, Friedrich (19251926): Die Grosse Politik der Europäischen Kabinette, 1871-1914. Sammlung der Diplomatischen Akten des Auswärtigen Amtes. Deutsche Verlagsgesellschaft für Politik und Geschichte, Berlin.

Lojkó Miklós (2010): Retrenchment at Home and Abroad. European Journal of English Studies (14) 3. pp. 281-293. 
doi: 10.14267/cojourn.2019v4n2a1

Lukacs, John (1988): Budapest 1900. A Historical Portrait of a City \& Its Culture. Grove Press, New York, 2012 [1988].

Lukacs, John (2013): A Short History of the Twentieth Century. The Belknap Press of Harvard University Press, Cambridge, MA, 2013.

Macmillan, Margaret (2001): Paris 1919: Six Months That Changed the World. Random House, London, 2001.

Manela, Erez (2007): The Wilsonian Moment. Self-Determination and the International Origins of Anticolonial Nationalism. Oxford University Press, Oxford, 2007.

Marks, Sally (2003): Marks on MacMillan, 'Paris 1919: Six Months That Changed the World'. H-Diplo Review. $\quad<$ https://networks.hnet.org/node/28443/reviews/30266/marks-macmillan-paris-1919-six-monthschanged-world > Accessed: April 20, 2019

Mavrogordatos, George Th. (2014): Cyprus and Greek Territorial Claims in World War I. The First World War and Cyprus, Nicosia, 26-27 September 2014. Conference paper.

McMeekin, Sean (2013): The Russian Origins of the First World War. The Balknap Press of Harvard University Press, Cambridge, MA—London, 2013.

Minasian, Sofiia-Kaneeva, Anna (2019): Témoignages sur les alsaciens-lorrains prisonniers dans le sud de la russie pendant la première guerre mondiale. Guerres mondiales et conflits contemporains 2017/1 ( $\left.\mathrm{N}^{\circ} 265\right)$. pp. 21-32.

Miquel, Pierre: La paix de Versailles et l'opinion publique française. Flammarion, Paris, 1972.

Mission Centenaire 14-18 (2019). < http://www.centenaire.org/fr > Accessed: 13 April, 2019

Morrow, John H. (2014): The imperial framework. The Cambridge History of the First World War. Vol. 1. Global War. Cambridge University Press, Cambridge.

Mulligan, William (2016): The Historiography of the Origins of the First World War. International Encyclopaedia of the First World War. <https://encyclopedia.1914$1918-$

online.net/article/the_historiography_of_the_origins_of_the_first_world_war > Accessed: April 20, 2019

Neil Harding (2009) [1977]: Lenin's Political Thought. Theory and Practice in the Democratic and Socialist Revolutions. Haymarket Books, Chicago. 
doi: 10.14267/cojourn.2019v4n2a1

Nicolson, Harold (1933): Peacemaking, 1919: Being Reminiscences of the Paris Peace Conference. Houghton Mifflin Company, Boston.

Nicolson, Harold (1946): The Congress of Vienna: A Study in Allied Unity, 1812-1822. Harcourt, Brace and Company, New York.

Nielson, Jonathan M. (1992): The Scholar as Diplomat: American Historians at the Paris Peace Conference of 1919. The International History Review (14) 2, 228-251.

Ninkovich, F. A. (1999): The Wilsonian Century: U.S. Foreign Policy Since 1900. University of Chicago Press, Chicago, IL.

Orzoff, Andrea (2009): Battle for the Castle. The Myth of Czechoslovakia in Europe, 1914-1948. Oxford, Oxford University Press.

Payk, Marcus M.-Pergher, Roberta (eds.) (2019): Beyond Versailles: Sovereignty, Legitimacy, and the Formation of New Polities after the Great War. Indiana University Press, Bloomington, IN., 2019.

Renouvin, Pierre: La traité de Versailles. Flammarion, Paris, 1969.

Révész Tamás (2017): 1918: az erőszak éve. Rubicon (29) 7-8. pp. 14-23.

Roberts, Priscilla (2006): World War I and Anglo-American Relations: The Role of Philip Kerr and The Round Table. The Round Table (95) 383. 113-139.

Romsics Ignác (2014): Trianon okai. A szembenézés narratívái a magyar történeti gondolkodásban. Hadtörténelmi szemle (127) 3. 663-691.

Sampaio, Guilherme (2016): The translation, diffusion, and reception of John Maynard Keynes's writings in France (1920s-50s). EUI PhD theses; Department of History and Civilization. European University Institute.

Sawicki, Gérald (2017): Proscrits, internés et exilés: le cas des alsaciens-lorrains prisonniers politiques dans l'empire allemand (1914-1918). Guerres mondiales et conflits contemporains 2017/1 ( $\left.\mathrm{N}^{\circ} 265\right)$. pp. 7-20.

Schmidt Mária (2019): Új világ született, 1918-1923. KKETTK Közalapítvány, Budapest, 2019.

Seton-Watson, Hugh (1926): Sarajevo: A Study in the Origins of the Great War. Hutchinson \& Co., London.

Sharp, Alan: A Comment. In: Boemeke, Manfred F.-Feldman, Gerald D.-Glaser, Elisabeth (eds.): The Treaty of Versailles. A Reassessment after 75 Years. Cambridge University Press, Cambridge.

Sharp, Alan: The Versailles Settlement: Peacemaking after the First World War, 19191923. Macmillan, London, 2018. 
doi: 10.14267/cojourn.2019v4n2a1

Sharp, Alan: The Versailles Settlement: Peacemaking in Paris, 1919. Macmillan, London, 1991.

Soutou, Georges-Henri (2014): Diplomacy. The Cambridge History of the First World War. Vol. 2. The State. Cambridge University Press, Cambridge, 2014.

Soutou, Georges-Henri: L'Or et le sang: Les Buts de guerre économiques de la Première Guerre mondiale. Fayard, Paris, 1989.

Stevenson, David: French War Aims and the American Challenge, 1914-1918. Historical Journal (22) 4. 877-894.

Stone, Norman (1966): Hungary and the Crisis of July 1914. Journal of Contemporary History (1) 3. p. 153-170.

Stone, Norman (1998): The Eastern Front 1914-1917. Penguin Books, London, 1998.

Tanner, Paul (2004): Six Views of the Paris Peace Conference. Journal of Humanities and Social Sciences 17. 49-60.

Taylor, A. J. P. (1945): The Course of German History. Hamish Hamilton, London.

Taylor, A. J. P. (1945): The Course of German History. Hamish Hamilton, London.

Taylor, A. J. P.: The Origins of the Second World War. Hamish Hamilton, London, 1961.

Trachtenberg, Marc: Versailles after Sixty Years. Journal of Contemporary History (17) 3. 487-506.

Trianon 100 (2019). <http://trianon100.hu/ > Accessed: 15 April, 2019

Widenor, William C. (1998): The Construction of the American Interpretation: The ProTreaty Version. In: Boemeke, Manfred F.-Feldman, Gerald D.-Glaser, Elisabeth (eds.): The Treaty of Versailles. A Reassessment after 75 Years. Cambridge University Press, Cambridge.

Xu, Guoqi: Asia. (2014): The Cambridge History of the First World War. Vol. 1. Global War. Cambridge University Press, Cambridge.

Zimmer, Oliver (2013): Nationalism in Europe, 1918-45. In. Breuilly, John (ed.): The Oxford Handbook of the History of Nationalism. Oxford, Oxford University Press. 